\section{Selective Native Plants of Oklahoma and Nearby States That Can Be a Nuisance to Occasionally Invasive}

\author{
Michael A. Schnelle ${ }^{1}$
}

ADDITIONAL INDEX WORDS. indigenous plants, herbaceous ornamentals, nursery crops, weed control, Salvia lyrata, Cornus drummondii, Chasmanthium latifolium, Cylindropuntia imbricata

SUMMARY. Four ornamental species, lyreleaf salvia (Salvia lyrata), roughleaf dogwood (Cornus drummondii), northern sea oats (Chasmanthium latifolium), and cholla (Cylindropuntia imbricata), are all native to Oklahoma and nearby states. They all possess ornamental attributes and range from widespread to niche crops in the nursery industry and are also cultivated for their utilitarian, herbal, and miscellaneous merits. Their allure to customers and their ability to thrive in a myriad of environments is a major impetus for commercial growers and retailers to carry these species. However, their extraordinary ability to adapt to a plethora of environmental conditions, in the built environment or in their native range, also enables them to often outcompete neighboring flora. Their predisposition to be opportunistic, and ability to grow in challenging locations, sometimes results in their becoming a nuisance or even invasive (i.e., capable of displacing other native flora or fauna). Plants featured are described for their marketable attributes but also reviewed for control measures (e.g., herbicides, prescribed burning, improved grazing practices) when they grow in an aggressive manner.

$\mathrm{W}$ holesalers, retailers, and end consumers should produce, sell, or grow environmentally appropriate plants in response to enhanced concerns among those seeking to protect and preserve the environment. Voluntarily acknowledging and practicing environmental stewardship, by reducing weedy to invasive plant spread, behooves all involved. From a historical perspective, North American nurseries were initiated in 1737 with concerted efforts by nurserypersons and plant explorers to

Received for publication 3 Jan. 2021. Accepted for publication 28 May. 2021

Published online 15 July 2021

${ }^{1}$ Department of Horticulture and Landscape Architecture, Oklahoma State University, 358 Agriculture Hall, Stillwater, OK 74078

This article was presented as part of the Invasive Plants Research Professional Interest Group workshop entitled "Progress in Identification and Control of Weedy to Invasive Plants both Domestic and Abroad" held on 12 Aug. 2020 during the virtual American Society for Horticultural Science's annual conference.

I thank Charles and Linda Shackelford, Shackelford Endowed Professorship in Floriculture, Oklahoma State University, for funding this project.

M.A.S. is the corresponding author. E-mail: mike. schnelle@okstate.edu.

This is an open access article distributed under the CC BY-NC-ND license (https://creativecommons. org/licenses/by-nc-nd/4.0/).

https://doi.org/10.21273/HORTTECH04791-20 introduce exotic species throughout the 18th and 19th centuries (Manks, 1968). Before the 1860s, most seed trade was local, direct from nursery personnel. However, with the advent of railroads, mail order became the norm as seed was transported rapidly across the United States. The ornamentals industry is without question a key source of nonnative species escaping from cultivation (Mack, 1991; Pysek et al., 2011; Reichard and White, 2001; van Kleunen et al., 2018), and it is thought that the industry has introduced in excess of 50,000 species to the United States for the nursery and landscape market (Gordon and Gantz, 2008) with up to $80 \%$ of inventory currently nonnative (Hulme et al., 2018). Accidental introductions through seed contaminants have also contributed to this problem (Lehan et al., 2013). However, based on a survey encompassing 6885 species grown by midAtlantic U.S. nurseries, only $4 \%$ were deemed invasive in the region served by these nurseries (i.e., Connecticut, Delaware, Maryland, New Jersey, New York, Pennsylvania, Virginia, West Virginia, and Washington, DC) (Coombs et al., 2020). In addition to the nursery industry, nonnative plants have been introduced to the United States via botanical gardens and arboreta, garden club and horticultural society seed exchanges, and the seed trade industry to meet medicinal and culinary demands, interest in personal aquaria and water gardens, and soil erosion mitigation needs (Reichard and White, 2001). Amatangelo and Ward (2018) discuss that property owners favored exotics over natives.

\section{Conflicting "invasive" definitions}

Experts' opinions or definitions as to what constitutes an invasive plant vary widely and is a contentious issue among academics (Frank, 2019; Richardson et al., 2008). Mooney and Cleland (2001) document invasive species as those that are introduced to a novel environment with negative ecological, economic, or social impacts. Reichard and White (2001) similarly defined an invasive plant as one that has (or is likely to) spread into native flora and managed plant systems, developed selfsustaining populations, and become dominant or disruptive (or both) in those systems. Beck et al. (2008) defined invasives as alien species whose introduction does or is likely to cause economic or environmental harm.

It has long been assumed that most aggressive plants are invasive species and are, by definition, nonnative, as they have invaded a habitat to which

\begin{tabular}{llll}
\hline $\begin{array}{l}\text { Units } \\
\begin{array}{l}\text { To convert U.S. to SI, } \\
\text { multiply by }\end{array}\end{array}$ & U.S. unit & SI unit & $\begin{array}{l}\text { To convert SI to U.S., } \\
\text { multiply by }\end{array}$ \\
\hline 0.4047 & acre $(\mathrm{s})$ & $\mathrm{ha}$ & 2.4711 \\
29.5735 & $\mathrm{fl} \mathrm{oz}$ & $\mathrm{mL}$ & 0.0338 \\
0.3048 & $\mathrm{ft}$ & $\mathrm{m}$ & 3.2808 \\
3.7854 & gal & $\mathrm{L}$ & 0.2642 \\
2.54 & inch $(\mathrm{es})$ & $\mathrm{cm}$ & 0.3937 \\
1.1209 & lb/acre & $\mathrm{kg} \cdot \mathrm{ha}^{-1}$ & 0.8922 \\
28.3495 & $\mathrm{Oz}$ & $\mathrm{g}$ & 0.0353 \\
70.0532 & $\mathrm{Oz} / \mathrm{acre}$ & $\mathrm{g} \cdot \mathrm{ha}^{-1}$ & 0.0143 \\
$\left({ }^{\circ} \mathrm{F}-32\right) \div 1.8$ & ${ }^{\circ} \mathrm{F}$ & ${ }^{\circ} \mathrm{C}$ & $\left({ }^{\circ} \mathrm{C} \times 1.8\right)+32$
\end{tabular}


they are not native. The U.S. Department of Agriculture (USDA), Natural Resources Conservation Service (2018) stops short of deeming native plants invasive, but does acknowledge the existence of opportunistic native plants. Their definition reads, "a native plant that is able to take advantage of disturbances to the soil or existing vegetation to spread quickly and outcompete the other plants on the disturbed site." However, it is becoming apparent that native species are not always "wellbehaved" and that some indigenous species can be as destructive and damaging as nonnative species. For example, a number of reports (e.g., Anderson, 2019; Anderson et al., 2021; Carey et al., 2012; Gettys, 2019; Kendle and Rose, 2000; Marble, 2018; Reichard and White, 2001; Robertson et al., 2020; Ruter, 2019; Schnelle, 2019; Schnelle and Gettys, 2021; Simberloff et al., 2012; Truong et al., 2020; Valery et al., 2009) acknowledge that native plant species can also exhibit behavior that ranges from weedy to invasive in natural areas as well as landscapes.

Native plants that can become invasive is not a phenomenon unique to the United States and can in fact be found globally (Canavan et al., 2019; MunozValles and Cambrolle, 2015). It is estimated that $10 \%$ to $20 \%$ of all invasive plants in North America are native to the United States (Nackley et al., 2017). Carey et al. (2012) report that natives can also cause ecological damage and economic impacts that rival high-profile invasive (exotic) species often attributed to human-mediated processes. Schnelle (2019) addresses five native ornamentals that can be a nuisance or even invasive under the right circumstances, becoming opportunistic with anthropogenic activities/disturbances often being the key catalyst. Native invaders complicate the development and implementation of countermeasures in science, management, society, and policy as a result of conflicting goals from diverse human interest and goals (Carey et al., 2012). Other indigenous ornamentals have also been reported to be weedy or invasive (Schnelle, 2019), with more than 50 U.S. native plant species perceived as invasive (Ellis, 2019; Linex, 2014; Simberloff et al., 2012). Conventional wisdom is shared by academics, horticultural practitioners, and consumers that native plants should be primarily or solely used in the United States to escape many of the consequences clearly documented regarding too many exotics.

Based on aforementioned citations, whether plant selection is as straightforward as once thought simply based on its nativity, is now in question. Besides the scientific community, avid gardeners are beginning to acknowledge that weediness and invasions can result from native plant materials (Ellis, 2019). Also, there are conflicting opinions on how to categorize native plants that are nuisances vs. those that are actually invasive; in other words, do they have the potential to simply be an inconvenience or annoyance, or are they displacing other native flora and/or fauna and disrupting ecological processes?

Given these diverse points of view, an impasse exists in reaching a consensus on what constitutes an "invasive" plant and how to mitigate invasions. A number of terms have been proposed to describe plants with aggressive growth regardless of origin (e.g., Colautti and Richardson, 2009; Pysek et al., 2004; Warren, 2007). Iannone et al. (2020) suggest seven terms (native, nonnative, introduced, established, invasive, nuisance, and range change) that can be used to describe any species; these terms are intuitive and easily understood, which should facilitate greater understanding and thus promote behavioral changes that support efforts to mitigate the negative impacts of invasive species.

ECONOMIC AND ECOLOGICAL CONSEQUENCES. The global economic and ecological ramifications of invasive plants are thoroughly documented and have been summarized elsewhere by a number of researchers (e.g., Bartz and Kowarik, 2019; Kettenring and Adams, 2011; Kueffer, 2017; Pysek et al., 2012; Weidlich et al., 2020). Invasive plants inflict harm in a number of ways, including reducing crop yields and pasture forage (Pimentel, 2009), interfering with native plant populations, and disrupting and altering hydrological processes (Pysek et al., 2012; Weidlich et al., 2020); pollination and soil stabilization are negatively affected as well (Pejchar and Mooney, 2009). Furthermore, invasive plants negatively impact native fauna (Fletcher et al., 2019) and have dire financial consequences, including human health risks (Rai and Singh, 2020). For example, invasive species (including plants, pathogens, and animals) cause damage valued at more than \$1.4 trillion globally, and economic damage from invasive plants in the United States alone is estimated to range from $\$ 40$ billion to $\$ 120$ billion annually (City of Portland, Oregon Bureau of Environmental Services, 2021; Diagne et al., 2020a, 2020b; Hanley and Roberts, 2019; Pimentel et al., 2000, 2005). Carey et al. (2012) report that natives can also cause ecological damage and economic impacts that rival high-profile invasive (exotic) species often attributed to humanmediated processes.

FACTORs OF Invasions. Invasions have occurred because of plant traits that favor drought tolerance, hardiness, ease of propagation, and rapid growth, which in turn makes these plants formidable invaders (Bell et al., 2003). Invasive plants are often more competitive than native species for a number of reasons, including enhanced resource uptake and use efficiency (Byun et al., 2018; Holzmueller and Jose, 2009). Rapid growth and reproduction rates of invasive species are often aggressive, resulting in dense monocultures that are not typically found in their native range (Hierro et al., 2005). Invasive plants may spread farther and faster when they have extensive underground root-like networks for rhizomes (Philip, 2017). Nonnative species may alter their invaded environment by producing allelochemicals that hinder native plant growth and vigor, lowering soil $\mathrm{pH}$, and altering nutrient cycling within the native stands (Bias et al., 2003; Callaway and Aschehoug, 2000). Phenotypic plasticity in some invasive plants enables them to tolerate a wide spectrum of environmental conditions, which expands potential sites they may invade; for example, fire can promote some invasive species, and some invasive species can promote fire (Brooks et al., 2004). Species growing outside their native range are not subject to attack by the coevolved specialist predators that keep their growth in check in their native range (i.e., "enemy release hypothesis"), and invasive species may be unpalatable, ignored, or subject to minimal damage from generalist enemies in their expanded territory (Keane and Crawley, 2002). 
Other factors can affect the survival and establishment of invasive species. For example, some nonnative species mimic native plants, which allows them to escape detection and grow unchallenged due to their resemblance to desirable vegetation (Barrett, 1983; Marble and Brown, 2021). Also, at least 263 species are reportedly resistant to herbicides, thus allowing them to survive and multiply unchecked despite attempted control measures (Heap, 2021). Current and future invasions are bolstered by the dearth of new herbicide chemistries, a result of commercial research and development operations shifting away from agrichemical development and focusing on the development of genetically modified crops (Phillips, 2020).

The built environment, sometimes referred to as built world, is another factor that can influence invasions and refers to the human-made environment that furnishes settings for human activity. In other words, it is the human-made space in which people live, work and recreate (Roof and Oleru, 2008). The subject of built environment also includes methods that municipalities approach environmental issues that have arisen as a result of altering the environment for human activities among those of plants and animals (Omer, 2015). With increasing urbanization, more people will be concentrated in high-density areas with the potential to create significant environmental degradation (Arnold, 2015) with alien species reportedly more closely associated with the urban environment than indigenous species (Williams et al., 2015). The built environment also is a factor influencing invasive plants, such as changes resulting from land subdivision and greater human presence exacerbating the vulnerability of landscapes to plant invasions (Klepeis et al., 2009). Invasives threaten built environments, including landscaping, infrastructure, industry, and gardens (Tomaselli, 2019). Biodiversity is adversely affected by the built environment, resulting in fragmentation and loss of habitat (Opoku, 2019).

Human-built environments can contribute to and interact with climate while also increasing air pollution and altering soils and hydrology (Grimm et al., 2008). Gulezian and Nyberg (2010) indicate that most species find opportunities for colonization and reproduction independent of land use in the built environment. Williams et al. (2015) suggest that the built environment may act as a sink for invasive plant species and that populations in forest preserves send more propagules into the built environment than they receive from it.

\section{Solutions}

Various plans have been proposed to discourage or "police" introductions of harmful nonnative species. Barbier et al. (2013) suggested that an annual license fee paid by the industry would reduce the risk of potentially dangerous introductions while raising funds for research, screening imported species, education, and the eradication of existing invasive populations. In contrast, Cordeiro et al. (2020) proposed targeting consumers by providing them with information about invasive plants, which could reduce or prevent introductions and bolster support for control interventions. In addition, voluntary codes of conduct have been adopted by botanic gardens and the horticulture industry to help interrupt the pathway of invasive plants (Heywood, 2014). The Missouri Invasive Plant Task Force (2020) is developing a state statute that would cease the sale, propagation, and intentional distribution of invasives. Best management practices are voluntary standards of practices sometimes suggested to aid in the management and control of invasive plants in built environments (Wisconsin Department of Natural Resources, 2019).

Last, cultivar trials and breeding efforts have focused on selecting for reduced fecundity or sterility (Contreras, 2010; Fetouh et al., 2020; Leonhardt, 2019; Ranney, 2006; Ruter, 2019; Trueblood et al., 2010; Vining et al., 2012; Wilson et al., 2021) to enable problematic species to continue to be marketed and sold but with less aggressive selections.

The purpose of this study was to highlight four commercially grown herbaceous or woody species that can be problematic in Oklahoma and other states, but have gone largely unaddressed. Although these Oklahoma natives are more of a nuisance or weedy plant rather than invasive in most settings, they still merit at the very least active surveillance. Outreach efforts could help industry and consumers be better poised should control measures be justified (plants aesthetically disrupt gardens or escape the built environment and/or begin growing outside their native range).

\section{Lyreleaf salvia (Salvia lyrata)}

Lyreleaf salvia is a perennial $2 \mathrm{ft}$ tall $\times 0.5 \mathrm{ft}$ wide and found growing in USDA Hardiness Zones 5 to 10. It can be found in the eastern United States, extending into parts of the midwest with it easily adapting in most of the country well beyond its native range (Dyer, 2020).

The species has a square/quadrangular stem arising from a basal rosette of leaves with flowers ranging in color from light blue to violet and located at the top of the stem from April to July. When cultivated or found growing naturally, en masse, flowers provide an impressive visual display followed by seedheads that readily open, dispersing wind-blown seed. Both stems and opposite leaves are pubescent, often developing deep lobing resembling the musical instrument, the lyre, thus the common name (Florida Wildflower Foundation, 2020). The basal leaves, often evergreen, are elongated and lobed or dissected, ranging from green to purple with considerable variation in leaf color and variegation within the species and its cultivars. Cultivars found in the ornamentals trade include Purple Volcano (Sedan Floral, Inc., 2021), Purple Knockout (New Moon Nursery, 2021), Burgundy Bliss (Broken Arrow Nursery, 2021), and others. Cultivars are usually noteworthy for their red to purple pigmented and sometimes mottled foliage. Many commercial growers promote and market the species on the foliage alone, with some of these cultivars creating even more intense purple to reddish-colored basal rosettes with the advent of cooler fall temperatures.

In cultivation, this species has been used as a groundcover, midheight hardy perennial, and wild flower. Lyreleaf salvia has been noted as a beneficial species to monarch butterflies (Danaus plexippus) in a number of migratory corridors and regions within the United States (Galea, 2015). The nectar-bearing flowers of this species also benefit 
hummingbirds, bees, and other pollinators with subsequent seeds eaten by songbirds.

Herbalists seek out this species for its medicinal values from all parts of the plant (Dirks, 2019), which was named Notable Native Herb of 2018 by the Herb Society of America. Long before, the Cherokee and Catawba Nations, and possibly others, found assorted medicinal uses including root salves for sores and infusions for colds and cough relief (Crooked Bear Creek Organic Herbs, 2018; Moerman, 1998). Young foliage has a slightly minty flavor (Dyer, 2020) and is appropriate for salads; edible flowers are often dried and brewed into tea (Vorderbruggen, 2006).

Valuable as an addition to unmowed roughs, lyreleaf salvia is one of many species comprising a stable groundcover to control erosion while also being aesthetically pleasing (Voigt, 2002). In lawns, lyreleaf salvia tolerates mowing as well as chronic foot traffic. Its inherent drought resistance and tolerance to also wet soils bodes well for justifying it in naturalized lawns. Given the nature of this species, it grows as a low-lying rosette form in roughs, naturalized lawns, or manicured lawns. The act of mowing often stimulates the plant to repeatedly flower and thus creates even greater seed production. Uttal (1963) discovered this species to sometimes have cleistogamic flowers (unopened flowers that can self-pollinate), which further enables this plant to be highly competitive in the landscape given its robust reproductive capacity. Lyreleaf salvia, without question, is in high demand as a versatile valuable ornamental and herb; it must be used in appropriate settings and consumers should be cautioned about its proclivity for weediness or occasional invasiveness. It is not a good choice for gardeners preferring tidy, manicured gardens (Dyer, 2020).

This assertive native (Wood, 2019) has an opportunistic nature and can thrive in disturbed areas as well as growing in many soil types (Pharr, 2020). Its ability to thrive in a wide range of conditions allows it to be competitive if not dominant in the landscape. Although a $\mathrm{pH}$ of 6.8 to 7.2 is ideal (Native Plants of North America, 2013), this species can be found growing in more acidic to more alkaline soils, again bolstering its adaptability and likelihood of weediness to invasiveness. Lyreleaf sage is often a lawn weed, and has been purposefully used in mixed-forbs lawn replacement studies (Moffis et al., 2021).

This native sage has been reported to displace desirable vegetation if not carefully managed. Voth (1984) found glyphosate at $0.42 \mathrm{~kg} \cdot \mathrm{ha}^{-1}$ provided lyreleaf salvia control in dormant bermudagrass (Cynodon dactylon). Furthermore, metsulfuron up to $0.5 \mathrm{oz} /$ acre provides adequate control (Boyd, 2016; Derr, 2012), whereas traditional lawn herbicides such as 2,4-D, dicamba and triclopyr are reportedly ineffective.

\section{Roughleaf dogwood (Cornus drummondii)}

Roughleaf dogwood is a clumping shrub to small tree that occasionally reaches up to $25 \mathrm{ft}$ tall $\times 15 \mathrm{ft}$ wide [often much smaller and shrublike (M.A. Schnelle, personal observation)] and grows in USDA Hardiness Zones 4 to 9 (Gilman and Watson, 2014). It has rough-textured foliage, thus its common name, with the Latin name honoring plant collector Thomas Drummond (1790-1835). Fourpetaled white flowers are abundant in flat-topped clusters or cymes. Devoid of showy bracts often associated with this genus, such as the more high-profile related species, flowering dogwood (Cornus florida), for example (Klingaman, 2014), roughleaf $\mathrm{dog}$ wood is not as well known by consumers. Abundant rounded, fleshy white fruit of 1/4-inch diameter mature by late summer. Fall foliage can sometimes be a rich burgundy hue, with deciduous winter stems also slightly red and showy (Morton Arboretum, 2019). Roughleaf dogwood occurs from Pennsylvania, Ohio and Michigan, west to South Dakota, south to Texas, and east to Mississippi (Breen, 2021).

Roughleaf dogwood can be found in woodland prairie margins, limestone glades, pastures, river bottoms, sandy stream banks, oak savannas, and open woods. It will grow in all soil types and tolerates extremes in topography and moisture regimes. Roughleaf dogwood is found along roadsides, fencerows, and ditches; swamps and marshes; wet to arid woods and thickets; lake and stream banks; limestone hills; and is commonplace in disturbed habitats.
Recommended for use in farmstead windbreaks, cover plantings, screening species, erosion control projects, or as an understory tree, it serves many niche purposes (Gardenia: Creating Gardens, 2020). Roughleaf dogwood serves as a wildlife food source, particularly when landscaping for bluebirds (Sialia sialis) and other birds (Zimmerman Smith, 2017) or when harsh conditions (i.e., full sun, wind-swept areas) preclude the use of more highly sought species with showy bracts, as alluded to earlier. Specialty nurseries also tout it for use in wetlands restoration projects.

Medicinally, the Iroquois nation made an infusion from stems to treat gonorrhea (Moerman, 1998). Because of the plant's aesthetic qualities, utilitarian usefulness, and its sheer tenacity to grow in a plethora of conditions, it is widely sought out throughout its natural growing range and beyond in the United States. Although this dogwood is not favored by nursery professionals to the degree that flowering dogwood or some of the other showybracted dogwoods are, it still is recommended for difficult sites and for its earlier described utilitarian purposes.

Dogwoods in general are early successional components of woodland ecosystems in North America and take advantage of open areas. They have a large number of seeds, vigorous seedlings, and dispersal by at least 40 species of birds (Gilman and Watson, 2014) with availability of perching sites influential (Smith, 1975). Also, their high tolerance to drought and shade position them to be one of the first species to inhabit areas (Morse, 2000). Roughleaf dogwood is versatile regarding growing sites and conditions, and this bolsters its ability to be very competitive, displacing other plants in the wild or in cultivation. Its invasive properties include accelerated vegetative reproduction, tolerance to wind, growth in full sun to partial shade, and drought tolerance (Morse, 2000). Birds spread its seeds but it also "migrates" asexually via underground shoot or rhizomatous growth.

Like a number of other dogwoods, roughleaf dogwood should be monitored, as it may dominate the understory of woods (A. Duxbury, unpublished data) and will invade grasslands without vigilant prescribed burning. Thickets of woody plants 
(such as roughleaf dogwood) invading floodplains can drastically alter wildlife habitat by diverting streams.

Roughleaf dogwood is one of several woody species that reduced channel area of the Platte River in Nebraska by $50 \%$ to $85 \%$, resulting in 97\% loss of roosting habitat for sandhill cranes (Antigone canadensis) and whooping cranes (Grus americana), along with other migratory birds (P. Currier, unpublished data). This species is also troublesome in the built environment (in cultivation) due to large number of seeds, rapid subsequent growth, dispersed by birds, and high tolerance to drought and shade (M.A. Schnelle, personal observation). Rapid and extensive cloning by rhizomatous growth allow dogwood to crowd out desired vegetation (Smith, 1975).

Roughleaf dogwood is topkilled by fire but resprouts readily; therefore, repeated burning (when plants are actively growing and not dormant is best), ideally in tandem with cutting and/or herbicide control, is usually required (Converse et al., 2020). Other control measures (Brunkow, 2009) include tebuthiuron pellets; triclopyr and 2,4-D; or picloram, 2,4-D amine, triclopyr treatments to achieve $70 \%$ defoliation. Thompson et al. (2009) also found effective control of dogwood with varying herbicide "cocktails," including triclopyr, 2,4-D and picloram; triclopyr and 2,4-D; and 2,4-D amine and dicamba (all within label rates). Most researchers and land managers used repeated chemical applications coupled with repeated prescribed burnings to effectively control this aggressive native.

Many foliar-applied herbicides such as dicamba, triclopyr used alone, or with 2,4-D will defoliate roughleaf dogwood but actual mortality is below 25\%. Fick (2018) states 50\% mortality or higher is achievable with a $1 \%$ solution of triclopyr plus fluroxypyr with the addition of $0.25 \%$ to $0.5 \%$ (by volume) nonionic surfactant further enhancing control. Tebuthiuron applied during the dormant season at $20 \mathrm{lb} /$ acre is also efficacious. By opening up the stand of roughleaf dogwood, chemically, a combination of a prescribed burning in late spring followed by another herbicide mix application 4 to 6 weeks after burning may provide even better control (Fick, 2018).

\section{Northern sea oats (Chasmanthium latifolium)}

Northern sea oats is a commercially important ornamental grass growing to $2.5 \mathrm{ft}$ tall $\times 1.5 \mathrm{ft}$ wide with foliage from afar superficially resembling bamboo (Bambusa sp.). The leaf blades are flat, have rough margins, and measure anywhere from 2 to 8 inches long $\times 7 / 8$ inch wide (Lindsey, 2020). Green, compressed spikelets (which look like overlapping fish scales) bloom in August-September turning golden brown and persisting into winter months (Stoner, 2020). Native to the eastern United States, this species has one selection, 'River Mist', coveted for its variegated foliage (Smith, 2017). This U.S. grass is host plant for several species of skipper butterflies and larval host to caterpillars of northern pearly eye butterflies (Enodia anthedon) (New Moon Nursery, 2020).

Northern sea oats is sought out for being highly deer resistant (Huckabee, 2014), as well as a superior grass for erosion control on slopes. Its high heat tolerance, ability to grow in deep shade, drought tolerance, and $\mathrm{pH}$ versatility further piques the interest of the green industry and consumers (Jackson, 2020). Besides aesthetic value, northern sea oats is ideal for wildlife food and habitat cover (Bidwell et al., 2004). Humans too have used it as a food source, specifically the Cocopah Nation using dried seeds that were ground and made into mush (Moerman, 1998).

Because it is likely one of the most shade-tolerant commercially available ornamental grasses on the market (New Moon Nursery, 2020), this attribute alone significantly elevates its popularity. However, from a weedy or invasive viewpoint, its desirable traits allow it to spread unchecked in shaded areas. Various institutions and mail order nurseries warn of this species' risk of becoming invasive (Gunnell et al., 2015; Stoner, 2020; Woodlanders, 2021). A number of universities caution using this species without forethought given that it can be significantly invasive via underground rhizomes and highly viable seeds. Allan Armitage remarks, "we have a few plants of our own that wear invasiveness with pride, and this is one of them (Roach, 2012).”

Removing seed heads before maturity will mitigate spread, but as a result, also negates the key ornamental feature. Although not ideal because this species prefers moist soils, growing northern sea oats under dry conditions will limit its rampant growth habit and thus is justified in certain settings. Two applications of topramezone herbicide at 0.5 or $0.10 \mathrm{~kg} \cdot \mathrm{ha}^{-1}$ at 6 - to 8 -week intervals resulted in 50\% injury or greater (Marble et al., 2018) with this species also sensitive to dimethenamid$\mathrm{P}$ and pendimethalin, or any grass herbicide at label rate. Repeat herbicide applications may be necessary with the risk of phytotoxicity to nearby desirable turfgrass.

\section{Cholla (Cylindropuntia imbricata)}

Cholla grows as a large shrub to tree-like in nature reaching 3 to $9 \mathrm{ft}$ height $\times 3$ to $4 \mathrm{ft}$ width (Halleck and Mackay, 2002), and is mostly restricted to seven states (Texas, Arizona, Colorado, Kansas, New Mexico, Oklahoma, and Utah) but grows in cultivated landscapes in USDA Hardiness Zones 6 to 11 (Provaznik, 2021). Cholla in cultivation is used for rock, desert, succulent, or Mediterranean gardens (Gardenia: Creating Gardens, 2020). Cholla bears 3 - to 4 -inch magenta-colored flowers (Provaznik, 2021) on stem tips that attract birds and pollinators during summer months. Yellow fruits follow flowers by late summer. The candelabra-like stems (Halleck and Mackay, 2002), ranging from 10 to 12 inches long, have 1 -inch spines (Provaznik, 2021) that can be silver to yellow, brown, or pink (Gardenia: Creating Gardens, 2020). The formidable spines of this species provide wildlife protection but also can injure wildlife and people. Cholla is not only cold hardy but also tolerates wet soils and thus is sought out by gardeners in frigid or humid climates. During the colder months, cholla stems develop a purplish cast lending winter interest. Given its versatility regarding growing conditions, and its ornamental value and utility in wildscapes, cholla is promoted by nurseries across the southwest United States.

Cholla is an ethnobotanically important plant with the western Keres nation making a paste from needle 
coverings to treat boils as well as using dried stems to treat earache and running ear. The Apache Nation ate cholla fruits, fresh, stewed, or dried (Moerman, 1998) with dye produced from fruit (Halleck and Mackay, 2002).

Although a coveted ornamental in the built environment, cholla can at times can be problematic in its native and extended range. Mirik et al. (2005) used hyperspectral remote sensing for mapping of unpalatable rangeland species including cholla. Overgrazing creates open areas in the herbaceous vegetation in which detached stems (joints) can root and initiate new plants (passive dispersal). Active dispersal occurs when animals defecate cholla seeds or when joints become lodged on fur and fall off at another location and root (Allen et al., 1991). The species appears to be spreading northeastward into Oklahoma and Kansas as a result of cattle ranching (Flora of North America, 2006). Greater densities have been observed in clay soils of Colorado (Kinraide, 1978), and found $43 \%$ higher population density of cholla in areas where competing herbaceous vegetation had been cleared. Miller et al. (2009) reported that tree cholla density increased significantly with increased elevation.

Cox and Johns (2014) determined dragged-rail treatments (iron rails dragged across rangeland by tractor knocking over plants and uprooting them) significantly reduced cholla infestation in southeast New Mexico. This practice is particularly effective when followed up by prescribed fire. Treated areas averaged 40 to 50 plants/ha; nontreated areas remained at 350 plants/ha. Mechanical control also should be executed during times of drought to minimize the risk of broken off joints/stems from rooting. Physical removal can be labor intensive and carries the risk of inadvertently disrupting desired vegetation in the process. Hand grubbing (physically removing plants by hand), too, may be effective for small-scale invasions. Excellent control results from combining 1 part dichlorprop and 3 parts diesel oil with 20 parts water (Young and Cram, 2018). Alternatively, these researchers report that 16 $\mathrm{oz}$ of picloram with $4 \mathrm{fl} \mathrm{oz}$ of wetting agent in $50 \mathrm{gal}$ of water also provided excellent control. It is important to note that cholla may not succumb to herbicide applications until 1 to 2 years after spray application. Treatments work best when temperatures are at least $60{ }^{\circ} \mathrm{F}$ (Young and Cram, 2018).

\section{Summary and conclusions}

Lyreleaf salvia, roughleaf dogwood, northern sea oats, and cholla, all have ornamental value in addition to their many utilitarian functions as pollinator plants, for erosion control, wildlife habitat, etc. These species can occasionally "go rogue" and thus require forethought with their use or exclusion made on a case-by-case basis. Green industry professionals and consumers must consider the built environment and question if these species would have an opportunity to invade degraded or open areas, environments with moisture extremes, highly shaded areas, etc., while weighing their merits vs. their potential weediness or even invasiveness (Marble, 2018; M.A. Schnelle, personal observation).

All four species described previously are currently being sold and marketed in their respective regions with no sales restrictions. None of the four species described in this paper warrant stopping sales from the ornamentals industry but do merit active surveillance over time and implementation of control measures when or if they cause aesthetic, economic, or ecological damage. Growing these plants from a commercial standpoint, or at the homeowner level, is a personal choice with the onus resting on all parties to weigh risks vs. rewards. Suffice it to say that all of the plants featured in this article are controversial with respect as to whether their aesthetic and/or utilitarian value outweighs their proclivity to be a nuisance or even invasiveness on occasion in the built environment or native range.

Davis et al. (2011) make the argument for conservationists to not judge species on their origin, but to focus instead on the functions of scrutinized species and less on where they originated. With warming average annual absolute minimum temperatures and anticipated shifts in cold hardiness zones, cultivated crops as well as native and alien species may achieve geographic expansion over time, resulting in additional challenges for land managers as well as those managing forests, rangelands, and other natural resources (Carey et al., 2012; Noss, 2001; Parker and Abatzoglou, 2016). Davis et al. (2011) suggested, regarding problematic native species, that conservationists and land managers should organize priorities based on whether species are producing benefits or harm to the biodiversity, human health, ecological services, and economics. Control measures should range from eradication to toleration of "new" species as enriching local biodiversity and facilitating ecosystem restoration as native communities reassemble and go forward under a new climate regime (Walther et al., 2009).

Industry is increasingly becoming more sensitive and receptive to choosing sterile or nearly sterile cultivars when available, regardless of origin (M.A. Schnelle, personal observation) with a 2015 survey of the southeastern nursery industry showing that $74 \%$ of participants indicated a positive opinion of sterility research and a willingness to promote sterile cultivars (Bechtloff et al., 2019). Datta et al. (2020) suggest means to identify safe cultivars of invasive plants that would in essence allow otherwise troubling species to be marketed and sold.

Speculating into the future, given the exponential increase in atmospheric carbon dioxide $\left(\mathrm{CO}_{2}\right)$ concentrations and the resulting impacts on climate, it is likely that both indigenous and nonnative plants will drastically alter ranges, resulting in the expansion of species in some situations but diminished ranges and populations in other scenarios (Nackley et al., 2017). Current management approaches must acknowledge that natural systems of the past are changing due to climate change, nitrogen eutrophication, increased urbanization, and other changes in land use (Davis et al., 2011). Ralph Waldo Emerson, an American essayist, philosopher, and poet, best addressed this debate with his remarks in 1878, "What is a weed? A plant whose virtues have yet to be discovered" (Rowe, 2011).

\section{Literature cited}

Allen, L.J.S., E.J. Allen, C.R.G. Kunst, and R.E. Sosebee. 1991. A diffusion model for dispersal of Opuntia imbricata (cholla) on 
rangeland. J. Ecol. 79:1123-1135, doi: https://doi.org/10.2307/2261103.

Amatangelo, K.L. and S.G. Ward. 2018. Suburban gardening in Rochester, New York: Exotic plant preference and risk of invasion. Landsc. Urban Plan. 180:161168, doi: https://doi.org/10.1016/j. landurbplan.2018.09.004.

Anderson, N.O. 2019. Throwing out the bathwater but keeping the baby: Lessons learned from purple loosestrife and reed canarygrass. HortTechnology 29:539_ 548, doi: https://doi.org/10.21273/ HORTTECH04307-19.

Anderson, N.O., A.G. Smith, A.K. Noyszewski, E. Ito, D. Dalbotten, and H. Pellerin. 2021. Management and control issues for native, invasive species (reed canarygrass): Evaluating philosophical, management and legislative issues. Hort Technology 31:354-366.

Arnold, M.A. 2015. ASHS presidential address: Relevancy in the corporate university - Horticulture's $21^{\text {st }}$ century challenge. HortScience 50:1838-1841, doi: https://doi.org/10.21273/HORTSCI.50. $12.1838 \mathrm{~b}$.

Barbier, E.B., D. Knowler, J. Gwatipedza, S.H. Reichard, and A.R. Hodges. 2013. Implementing policies to control invasive plant species. Bioscience 63:132-138, doi: https://doi.org/10.1525/bio.2013. 63.2.9.

Barrett, S.C.H. 1983. Crop mimicry in weeds. Econ. Bot. 37:255-282, doi: https://doi.org/10.1007/BF02858881.

Bartz, R. and I. Kowarik. 2019. Assessing the environmental impacts of invasive alien plants: A review of assessment approaches. NeoBiota 43:69-99, doi: https://doi.org/ $10.3897 /$ neobiota.43.30122.

Bechtloff, A., C. Reinhardt Adams, S. Wilson, Z. Deng, and C. Wiese. 2019. Insights from southeastern US nursery growers guide research for sterile cultivars. J. Environ. Hort. 37:9-18, doi: https:// doi.org/10.24266/0738-2898-37.1.9.

Beck, K.G., K. Zimmerman, J.D. Schardt, J. Stone, R.R. Lukens, S. Reichard, J. Randall, A.A. Cangelosi, D. Cooper, and J.P. Thompson. 2008. Invasive species defined in a policy context: Recommendations from the federal invasive species advisory committee. Invasive Plant Sci. Manag. 1:414-421, doi: https://doi.org/10.1614/IPSM-08089.1.

Bell, C.E., C.A. Wilen, and A.E. Stanton. 2003. Invasive plants of horticultural origin. HortScience 38:14-16, doi: https:// doi.org/10.21273/HORTSCI.38.1.14.

Bias, H.P., R. Vepachedu, S. Gilroy, R.M. Callaway, and J.M. Vivanco. 2003.
Allelopathy and exotic plant invasion: From molecules and genes to species interactions. Science 301:1377-1380, doi: https://doi.org/10.1126/

science. 1083245

Bidwell, T., R.E. Masters, and R.J. Tyrl. 2004. A checklist of prairie, shrubland, and forest understory plants of Oklahoma. Oklahoma Coop. Ext. Serv. NREM 2872.

Boyd, J. 2016. Turfgrass weed control. Univ. Ark. Coop. Ext. Publ. MP 521. 5 Oct. 2020. <https://www.uaex.edu/ publications/PDF/MP521.pdf?>.

Breen, P. 2021. Cornus drummondii. 4 July 2021. <https://www.landsc apeplants.oregonstate.edu/plants/cornusdrummondii $>$.

Broken Arrow Nursery. 2021. Salvia lyrata 'Burgundy Bliss'. 5 May 2021. <https://www.brokenarrownursery.com/ burgundy-bliss-lyreleaved-sage.html $>$.

Brooks, M.L., C.M. D'Antonio, D.M. Richardson, J.B. Grace, J.E. Keeley, J.M. DiTomaso, R.J. Hobbs, M. Pellant, and D. Pyke. 2004. Effects of invasive alien plants on fire regimes. Bioscience 54:677-688.

Brunkow, G.E. 2009. Chemical control of rough-leaved dogwood. Kansas State Univ., Manhattan, MS Thesis.

Byun, C., S. de Blois, and J. Brisson. 2018. Management of invasive plants through ecological resistance. Biol. Invas. 20:13-27, doi: https://doi.org/10.1007/s10530017-1529-7.

Callaway, R.M. and E.T. Aschehoug. 2000. Invasive plants versus their new and old neighbors: A mechanism for exotic invasion. Science 290:521-523, doi: https://doi. org/10.1126/science.290.5491.521.

Canavan, S., S. Kumschick, J.J. LeRoux, D.M. Richardson, and J.R.U. Wilson. 2019. Does origin determine environmental impacts? Not for bamboos. Plants People Planet 1:119-128, doi: https:// doi.org/10.1002/ppp3.5.

Carey, M.P., B.L. Sanderson, K.A. Barnas, and J.D. Olden. 2012. Native invaders: Challenges for science, management, policy, and society. Front. Ecol. Environ. 10:373-381, doi: https://doi.org/10.1890/110060.

City of Portland, Oregon Bureau of Environmental Services. 2021. The problem with invasive plants. 24 Feb. 2021. <https://www.portlandoregon.gov/bes/ article/330681 $>$.

Contreras, R. 2010. Reigning in rogues: Developing sterile forms of nursery crops. Master gardener mini-college, Corvallis, OR. 26 Mar. 2021. < https:www.diggermagazine. com>.
Converse, C., N. Eckhardt, and L. Morse. 2020. Roughleaf dogwood. 15 Oct. 2020. $<$ https://explorer.naturereserve.org/ Taxon/ELEMENT_GLOBAL.2.148084? Cornus_drummondii $>$.

Coombs, G., D. Gilchrist, and P. Watson. 2020. An assessment of the native and invasive horticultural plants sold in the mid-Atlantic region. Native Plants J. 21:74-82, doi: https://doi.org/10.3368/npj.21.1.74.

Cordeiro, B., H. Marchante, P. Castro, and E. Marchante. 2020. Does public awareness about invasive plants pay off? An analysis of knowledge and perceptions of environmentally aware citizens of Portugal. Biol. Invas. 22:2267-0081, doi: https:// doi.org/10.1007/s10530-020-02247-z.

Colautti, R.I. and M. Richardson. 2009. Subjectivity and flexibility in invasion terminology: Too much of a good thing? Biol. Invas. 11:1225-1229, doi: https:// doi.org/10.1007/s10530-008-9333-z.

Cox, R.D. and B.G. Johns. 2014 Dragged-rail treatments for reducing cholla infestation in southeast New Mexico, USA. Weed Technol. 28:286-289, doi: https:// doi.org/10.1614/WTY-D-13-00110.1.

Crooked Bear Creek Organic Herbs. 2018. Getting to know lyre-leaf sage. 14 June 2020. <https://crookedbearcreekorganic herbs.com/2018/07/04/getting-to-knowlyre-leaf-sage $/>$.

Datta, A., S. Kumschick, S. Geerts, and J.R.U. Wilson. 2020. Identifying safe cultivars of invasive plants: Six questions for the risk assessment, management, and communication. NeoBiota 62:81-97, doi: https:// doi.org/10.3897/neobiota.62.51635.

Davis, M., M.K. Chew, R.J. Hobbs, A.E. Lugo, J.J. Ewel, G.J. Vermeij, J.H. Brown, M.I. Rosenzweig, M.R. Gardener, S.P. Carroll, K. Thompson, S.T.A. Pickett, J.C. Stromberg, P.D. Tredici, K.N. Suding, J.G. Ehrenfeld, J.P. Grime, J. Mascarao, and J.C. Briggs. 2011. Don't judge species on their origins. Nature 474:153-154, doi: https://doi.org/10.1038/474153a.

Derr, J.F. 2012. Broadleaf weed control with sulfonylurea herbicides in cool-season turfgrass. Weed Technol. 26:582-586, doi: https://doi.org/10.1614/WT-D-11-00 166.1.

Diagne, C., J.A. Carford, F. Essl, M.A. Nunez, and F. Courchamp. 2020a. What are the economic costs of biological invasions? A complex topic requiring international and interdisciplinary expertise. NeoBiota 63:25-37, doi: https://doi. org/10.3897/neobiogta.63.55260.

Diagne, C., B. Leroy, R.E. Gozlan, A.C. Vaissieere, C. Assailly, L. Nuninger, D. Roiz, F. Jourdain, I. Jaric, and F. Courchamp. 2020b. InvaCost, a public database of 
the economic costs of biological invasions worldwide. Sci. Data 7:277, doi: https:// doi.org/10.1038/s41597-020-00586-z.

Dirks, D. 2019. Lyre-leaf sage (wild) bee friendly, medicinal, and historically significant herb. 22 Oct. 2020. <https://the gardenladyofga.org.wordpress.com/2019/ 04/23/lyre-leaf-sage-wild-bee-friendlymedicinal-and-historically-ignificant-herb/ $>$.

Dyer, M.H. 2020. Lyreleaf sage care: Tips on growing lyreleaf sage. 11 Dec. 2020. <https://gardeningknowhow.com/ ornamental/flowers/salvia/growing-lyreleafsage.htm>.

Ellis, M.E. 2019. Invasive native plants: Can native plants become invasive? 6 Oct. 2020. $<$ https://gardeningknowhow.com/plantproblems/weeds/can-native-plants-becomeinvasive $. h t m /$ ?print $=1$ \&loc $=$ bot $>$.

Fetouh, M.I., Z. Deng, S.B. Wilson, C.R. Adams, and G.W. Knox. 2020. Induction and characterization of tetraploids in chinese privet (Ligustrum sinense Lour.). Scientia Hort. 271:109482, doi: https:// doi.org/10.1016/j.scientia.2020.109482.

Fick, W.H. 2018. Chemical control of roughleaf dogwood and smooth sumac. 4 Dec. 2020. <https://webapp.agron.ksu. edu/agr_social/m_eu_article.throck? article_id $=1860>$.

Fletcher, R.A., R.K. Brooks, V.T. Lakoba, G. Sharma, A.R. Heminger, C.C. Dickinson, and J.N. Barney. 2019. Invasive plants negatively impact native, but not exotic animals. Glob. Change Biol. 25:3694-3705, doi: https://doi.org/10.1111/gcb.14752.

Flora of North America. 2006. Cylindropuntia imbricata. 11 Sept. 2020. <https:// www.efloras.org/florataxon.aspx?flora_id= 1\&taxon_id=242415157>.

Florida Wildflower Foundation. 2020. Flower Friday: Lyreleaf sage. 10 Mar. 2021. $<$ flawildflowers.org/flower-friday-salvialyrata/>.

Frank, D.M. 2019. Disa greement or denialism? "Invasive species denialism" and ethical disagreement in science. Synthese, doi: https://doi.org/10.1007/ sl 1229-019-02259-w.

Galea, M. 2015. Conservation and management of monarch butterflies. Pollinator partnership. 15 Nov. 2020. <https:// www.pollinator.org/monarch/monarchresources $>$.

Gardenia: Creating Gardens. 2020. Cylindropuntia imbricata (tree cholla). 12 Feb. 2021. <https://gardenia.net/plant/cylin dropuntia-imbricata $>$.

Gettys, L.A. 2019. Breaking bad: Native aquatic plants gone rogue and the invasive species that inspire them.
HortTechnology 29:559-566, doi: https://doi.org/10.21273/

HORTTECH043

33-19.

Gilman, E.F. and D.G. Watson. 2014. Cornus drummondii: Roughleaf dogwood. 10 Mar. 2021. <https://edis.ifas. ufl.edu/s1184>.

Gordon, D.R. and C.A. Gantz. 2008. Screening new plant introductions for potential invasiveness: A test of impacts for the United States. Conserv. Lett. 1: 227-235, doi: https://doi.org/10.1111/ j.1755-263X.2008.00032.x.

Grimm, N.B., S.H. Faeth, N.E. Golubiewski, C.L. Redman, J. Wu, X. Bai, and J.M. Briggs. 2008. Global change and the ecology of cities. Science 319:756-760, doi: https://doi.org/10.1126/science. 1150195 .

Gulezian, P.Z. and D.W. Nyberg. 2010. Distribution of invasive plants in a spatially structured urban landscape. Landsc. Urban Plan. 95:161-168, doi: https://doi. org/10.1016/j.landurbplan.2009.12.013.

Gunnell, J., J.L. Goodspeed, and R.M. Anderson. 2015. Ornamental grasses in the landscape: A guide for the Intermountain West. 11 Jan. 2021. <https://digital commons.usu.edu/extension_curall $/ 733 />$.

Halleck, L. and W. Mackay. 2002. Texas native plants database: Opuntia imbricata (Cylindropuntia imbricata). 14 Mar. 2021. <https://aggie-horticulture tamu. edu/ornamentals/nativeshrubs/opuntiaim bricat.htm $>$.

Hanley, N. and M. Roberts. 2019. The economic benefits of invasive species management. People Nat. 1:124-137, doi: https://doi.org/10.1002/pan3.31.

Heap, I. 2021. The international herbicideresistant weed database. 16 Feb. 2021. $<$ www.weedscience.org/Home.aspx $>$.

Heywood, V. 2014. Voluntary codes of conduct for botanic gardens and horticulture and engagement with the public. EPPO Bul. 44:223-231, doi: https:// doi.org/10.1111/epp.12112.

Hierro, J.L., J.L. Maron, and R.M. Callaway. 2005. A biogeographical approach to plant invasions: The importance of studying exotics in their introduced and native range. J. Ecol. 93:5-15, doi: https://doi.org/ 10.1111/j.0022-0477.2004.00953.x.

Holzmueller, E.J. and S. Jose. 2009. Invasive plant condundrum: What makes aliens so successful? J. Trop. Agr. 47(1-2): 18-29.

Huckabee, T. 2014. Inland sea oats (Chasmanthium latifolium): A seasonal look. 9 July 2020. <https://mygardener says.com/2014/12/29/inland-sea-oatschasmanthium-latifolium $/>$.

Hulme, P.E., G. Brundu, M. Carboni, K. Dehnen-Schmutz, S. Dullinger, R. Early, F. Essl, P. Gonzalez-Moreno, Q.J. Groom, C. Kueffer, I. Kuhn, N. Maurel, A. Novoa, J. Pergl, P. Pysek, H. Seebens, R. Tanner, J.M. Touza, M. van Kleunen, and L.N.H. Verbrugge. 2018. Integrating invasive species policies across ornamental horticulture supply-chains to prevent plant invasion. J. Appl. Ecol. 55:92-98, doi: https://doi.org/10.1111/1365-2664. 12953.

Iannone, B.V., III, S. Carnevale, M.B. Main, J.E. Hill, J.B. McConnell, S.A. Johnson, S.F. Enloe, M. Andreu, E.C. Bell, J.P. Cuda, and S.M. Baker. 2020. Invasive species terminology: Standardizing for stakeholder education. J. Ext. 58(3):a3. <https://tigerprints.clemson. edu/joe/vol58/iss3/27/>.

Jackson, M. 2020. Inland sea oats, wood oats. 7 July 2020. <https://www.depts. ttu.edu/plantresources/Pages/Landscape_ Information_Sheets/Herbaceous_Info/ Chasmanthium_latifolium.php $>$.

Keane, R.M. and M.J. Crawley. 2002. Exotic plant invasions and the enemy release hypothesis. Trends Ecol. Evol. 17: 164-170, doi: https://doi.org/10.1016/ S0169-5347(02)02499-0.

Kendle, A.D. and J.E. Rose. 2000. The aliens have landed! What are the justifications for "native only" policies in landscape plantings? Landsc. Urban Plan. 47:19-31, doi: https://doi.org/10.1016/S0169-2046 (99)00070-5.

Kettenring, K.M. and C.R. Adams. 2011. Lessons learned from invasive plant control experiments: A systematic review and metaanalysis. J. Appl. Ecol. 48:970-979, doi: https://doi.org/10.1111/j.1365-2664. 2011.01979.x.

Kinraide, T.B. 1978. The ecological distribution of cholla cactus [Opuntia imbricata (Haw.) DC.] in El Paso County, Colorado. Southwest. Nat. 23:117-134.

Klepeis, P., N. Gill, and L. Chisholm. 2009. Emerging amenity landscapes: Invasive weeds and land subdivision in rural Australia. Land Use Policy 26:380-392, doi: https://doi.org/10.1016/JLAND USEPOL.2008.04.006.

Klingaman, G. 2014. Plant of the week: Dogwoods (Cornus), shrub (Swida). 15 Nov. 2020. <https://www.uaex.edu/ yard-garden/resource-library/plant-week/ dogwoods-native-8-22-2014.aspx $>$.

Kueffer, C. 2017. Plant invasions in the anthropocene. Science 358:724-725, doi: https://doi.org/10.1126/science.aao6371. 
Lehan, N.E., J.R. Murphy, L.P. Thorburn, and B.A. Bradley. 2013. Accidental introductions are an important source of invasive plants in the continental United States. Amer. J. Bot. 100:1287-1293, doi: https://doi.org/10.3732/ajb.1300061.

Leonhardt, K.W. 2019. Polyploidy as a management strategy for invasive species. HortTechnology 29:554-558, doi: https://doi.org/10.21273/HORTTECH 04324-19.

Lindsey, M. 2020. Broad-leaf wood oats. 13 Mar. 2021. <https://homesteadon therange.com $/ 2020 / 08 / 31 /$ broad-leafwood-oats? $>$

Linex, R. 2014. Can a native plant be noxious or invasive? 6 July 2018. <https:// npsot.org/wp/story/2014/6872/>.

Mack, R.N. 1991. The commercial seed trade: An early disperser of weeds in the United States. Econ. Bot. 45:257-273, doi: https://doi.org/10.1007/BF02862053.

Manks, D.D. 1968. How the American nursery trade began, p. 4-11. In: D.S. Manks (ed.). Origins of American horticulture: A handbook. Brooklyn Botanic Garden, Brooklyn, NY.

Marble, S.C. 2018. Native weedy pests of the deep south. HortScience 53:12441249, doi: https://doi.org/10.21273/ HORTSCI13112-18.

Marble, S.C. and S.H. Brown 2021. Invasive plants with native lookalikes: How mistaken identities can lead to more significant plant invasions and delay management. HortTechnology 31:385-394.

Marble, S.C., M.T. Elmore, and J.T. Brosnan. 2018. Tolerance of native and ornamental grasses to over-the-top applications of topramezone herbicide. HortScience 53:842-849, doi: https://doi. org/10.21273/HORTSCI1298.

Miller, T.E.X., S.M. Louda, K.A. Rose, and J.O. Eckberg. 2009. Impacts of insect herbivory on cactus population dynamics: Experimental demography across an environmental gradient. Ecol. Monogr. 79: 155-172, doi: https://doi.org/10.1890/ 07-1550.1.

Mirik, M., G.J. Michels, Jr., S. Kassymzhanova-Mirik, D. Jones, and N.C. Elliott. 2005. Spectral properties of tree cholla and yucca measured by an airborne hyperspectral sensor and the resulting maximum likelihood classification of rangelands. 20th Biennial Workshop on Aerial Photography, Videography, and High Resolution Digital Imagery for Resource Assessment, 4-6 Oct. 2005, Weslaco, TX.

Missouri Invasive Plant Task Force. 2020. Missouri invasive plant task force definitions: Native, invasive, aggressive and non-native.
5 Mar. 2021. <https://moinvasives.org/ invasive-plant-definitions-native-invasiveaggressive $/>$.

Moerman, D.E. 1998. Native American ethnobotany. Timber Press, Portland, OR.

Moffis, B., B. Iannone, W. Wilber, A. Dale, B. Unruh, J. Rycyna, and S.B. Wilson. 2021. Multispecies lawns: An alternative strategy for water conservation and ecosystem functions. Proc. Florida. State Hort. Soc. 133:189-194.

Mooney, H.A. and E.E. Cleland. 2001. The evolutionary impact of invasive species. Proc. Natl. Acad. Sci. USA 98:5446-5451, doi: https://doi.org/10.1073/pnas.091 093398 .

Morse, L. 2000. Cornus drummondii. 9 Mar. 2021. <https://explore natureserve. org/Taxon/ELEMENT_GLOBAL.2.148 084/Cornus_drummondii $>$.

Morton Arboretum. 2019. Roughleaf dogwood. 11 Mar. 2021. < https://mortonarb. org/trees-plants/tree-plant-descriptions / rough-leaved-dogwood/ $>$.

Munoz-Valles, S. and J. Cambrolle. 2015. The threat of native-invasive plant species to biodiversity conservation in coastal dunes. Ecol. Eng. 79:32-34, doi: https:// doi.org/10.1016/j.ecoleng.2015.03.002.

Nackley, L.L., A.G. West, A.L. Skowno, and W.J. Bond. 2017. The nebulous ecology of native invasions. Trends Ecol. Evol. 32:814-824, doi: https://doi.org/ 10.1016/j.tree.2017.08.003.

Native Plants of North America. 2013. Salvia lyrata. 12 Feb. 2021. https:// www.wildflower.org/plants/result.php? id_plant $=$ saly $>$.

New Moon Nursery. 2020. Chasmanthium latifolium. 18 Oct. 2020. <https://www.newmoonnursery.com/ plant/Chasmanthium-latifolium $>$.

New Moon Nursery. 2021. Salvia lyrata 'Purple Knockout'. 10 May 2021. <https://www.newmoonnursery.com/ plant/Salvia-lyrata-Purple-Knockout $>$.

Noss, R.F. 2001. Beyond Kyoto: Forest management in a time of rapid climate change. Conserv. Biol. 282:578-590, doi: https://doi.org/10.1046/j.1523-1739. 2001.015003578.x.

Omer, A.M. (ed.). 2015. Built environment: Identifying, developing and moving sustainable communities through renewable energy. Nova Science, Hauppauge, NY.

Opoku, A. 2019. Biodiversity and the built environment: Implications for the sustainable development goals (SDGs). Resour. Conserv. Recycling 141:1-7, doi: https://doi.org/10.1016/j.resconrec. 2018.10.011.

Parker, L.E. and J.T. Abatzoglou. 2016. Projected changes in cold hardiness zones and suitable overwinter ranges of perennial crops over the United States. Environ. Res. Lett. 11:034001, doi: https://doi.org/ 10.1088/1748-9326/11/3/034001.

Pejchar, L. and H.A. Mooney. 2009. Invasive species, ecosystem services and human well-being. Trends Ecol. Evol. 24: 497-504, doi: https://doi.org/10.1016/ j.tree.2009.03.016.

Pharr, W. 2020. A floristic survey of Andalusia: A historic preservation site in Baldwin County, Georgia. 18 Nov. 2020. $<$ https://kb.gcsu.edu/biology/8 > .

Philip, L. 2017. Invasive plants vs. aggressive weeds: Planting knowledge. 11 Jan. 2021. <https://soiladvocates.ca/invasiveplants-vs-weeds $/>$.

Phillips, M.W.A. 2020. Agrochemical industry development, trends in R\&D and the impact of regulation. Pest Manag. Sci. 76:3348-3356, doi: https://doi. org/10.1002/ps.5728.

Pimentel, D. 2009. Invasive plants: Their role in species extinction and economic losses to agriculture in the U.S.A., p. 1-7. In: Inderjit (eds.) Management of invasive weeds, Invading nature. Springer, Dordrecht, The Netherlands, doi: https:// doi.org/10.1007/978-1-4020-9202-2_1.

Pimentel, D., L. Lach, R. Zuniga, and D. Morrison. 2000. Environmental and economic costs of nonindigenous species in the United States. Bioscience 50:53-65, doi: https://doi.org/10.1641/0006-3568 (2000)050[0053:EAECON]2.3.CO;2.

Pimentel, D., R. Zuniga, and D. Morrison. 2005. Update on the environmental and economic costs associated with alien-species in the United States. Ecol. Econ. 52: 273-288, doi: https://doi.org/10.1016/j. ecolecon.2004.10.002.

Provaznik, M. 2021. Cold-hardy cacti for the mountain West. 25 Mar. 2021. <https://finegardening.com/article/ cold-hardy-cacti-for-the-mountain-west $>$.

Pysek, P., D.M. Richardson, M. Rejmanek, G.L. Webster, M.K. Williamson, and J. Kirschner. 2004. Alien plants in checklists and floras: Towards better communication between taxonomists and ecologists. Taxon 53:131-143, doi: https://doi.org/10.2307/4135498.

Pysek, P., V. Jarosik, and J. Pergl. 2011. Alien plants introduced by different pathways differ in invasive success: Unintentional introductions as a threat to natural areas. PLoS One 6:e24890, doi: https:// doi.org/10.1371/journal.pone.0024890. 
Pysek, P., V. Jarosik, P.E. Hulme, J. Pergl, M. Hejda, U. Schaffner, and M. Vila. 2012. A global assessment of invasive plant impacts on resident species, communities and ecosystems: The interaction of impact measures, invading species' traits and environment. Glob. Change Biol. 18:1725-1737, doi: https://doi.org/ 10.1111/j.1365-2486.2011.02636.x.

Rai, P.K. and J.S. Singh. 2020. Invasive alien plant species: Their impact on environment, ecosystem services and human health. Ecol. Indic. 111:106020, doi: https://doi. org/10.1016.j.ecolind.2019.106020.

Ranney, T.G. 2006. Polyploidy: From evolution to new plant development. Comb. Proc. Intl. Plant Prop. Soc. 56:137-142.

Reichard, S.A. and P. White. 2001. Horticulture as a pathway of invasive plant introductions in the United States. Bioscience 51:103-113, doi: https://doi.org/ 10.1641/0006-3568(2001)051[0103: HAAPOI $] 2.0 . \operatorname{co} ; 2$.

Richardson, D.M., P. Pysek, D. Simberloff, M.G. Rejmanek, and A.D. Mader. 2008. Biological invasions: The widening debate. Prog. Hum. Geogr. 32:295-298, doi: https://doi.org/10.1177/03091325070 88313.

Roach, M. 2012. Chasmanthium, a native grass for shade. 13 Oct. 2020. <https:// awaytogarden.com/chasmanthium-a-nativegrass-for-shade $/>$.

Robertson, P.A., A. Mill, A. Novoa, J.M. Jeschke, F. Essl, B. Gallardo, J. Geist, I. Jaric, X. Lambin, C. Musseau, J. Pergl, P. Pysek, W. Rabitsch, M. von Schmalensee, M. Shirley, D.L. Strayer, R.A. Stefansson, K. Smith, and O. Booy. 2020. A proposed unified framework to describe the management of biological invasions. Biol. Invas. 22:2633-2645, doi: https://doi. org/10.1007/s10530-020-02298-2.

Roof, K. and N. Oleru. 2008. Public health: Seattle and King county's push for the built environment. J. Environ. Health 71:24-27.

Rowe, K.T. 2011. Lyre leaf sage. 13 Nov. 2020. <https://herberowe.wordpress.com/ 2011/06/03/lyre-leaf-sage-salvia-lyrata/> .

Ruter, J.M. 2019. Inducing sterility in carolina cherry laurel using gamma irradiation. HortTechnology 29:535-538, doi: https://doi.org/10.21273/HORTTECH 04289-19.

Schnelle, M.A. 2019. Workshop: Native woody plants of the southern United States with weedy or invasive tendencies: A review of common offenders. HortTechnology 29:567-570, doi: https://doi.org/10. 21273/HORTTECH04334-19.
Schnelle, M.A. and L.A. Gettys. 2021. Nuisance to invasive ornamentals: Proceedings from the ASHS invasive plants research group 2020 workshop. HortTechnology 31:339-342.

Sedan Floral, Inc. 2021. Salvia lyrata 'Purple Volcano'. 4 May 2021. <https:// www.sedanfloral.com/Plant-Name/Salvialyrata-Purple-Volcano $>$.

Simberloff, D., L. Souza, M.A. Nunez, M.N. Barros-Garcia, and W. Bunn. 2012. The natives are restless, but not often and mostly when disturbed. Ecology 93:598607, doi: https://doi.org/10.1890/111232.1.

Smith, A.J. 1975. Invasion and ecesis of bird-disseminated woody plants in a temperate forest sere. Ecology 56:19-34.

Smith, B. 2017. Ornamental grasses and grass-like plants. Clemson Coop. Ext. Factsheet HGIC 1178. 11 Aug. 2020. <https://hgic.clemson.edu/factsheet/ ornamental-grasses-and-grsass-like-plants $>$.

Stoner, N. 2020. Northern sea oats. 20 Oct. 2020. < https://communityenviron ment.unl.edu/northern-sea-oats $>$.

Thompson, C.R., D.E. Peterson, W.H. Fick, P.W. Stahlman, and R.E. Wolf. 2009. Chemical weed control for field crops, pastures, rangeland, and noncropland. Kans. State Univ. Agr. Expt. Sta. Coop. Ext. Ser. Rept. Prog. SRP 1007.

Tomaselli, J. 2019. Invasive species. 15 Mar. 2021. <https://ccedutchess.org/ environment/invasives-species/ $>$.

Trueblood, C.E., T.G. Ranney, N.P. Lynch, J.C. Neal, and R.T. Olsen. 2010. Evaluating fertility of triploid clones of Hypericum androsaemum L. for use as non-invasive landscape plants. HortScience 45:1026-1028, doi: https://doi. org/10.21273/HORTSCI.45.7.1026.

Truong, T.T.A., M.E. Andrew, G.E. St. Hardy, T.Q. Pham, Q.H. Nguyen, and B. Dell. 2020. Impact of a native invasive weed (Microstegium ciliatum) on regeneration of a tropical forest. Plant Ecol. 222:173-191, doi: https://doi.org/ 10.1007/s11258-020-01097-y.

U.S. Department of Agriculture, Natural Resources Conservation Service. 2018. Native, invasive, and other plant related definitions. 11 Oct. 2020. <https://www. nrcs.usda.gov/wps/portal/nrcs/detail/ct/ technical/ecoscience/invasive/?cid=nrcs 142p2_304011124>.

Uttal, L.J. 1963. Cleistogamy in Salvia lyrata. Castanea 28(4):162-164.

Valery, L., H. Fritz, J.-C. Lefeuvre, and D. Simberloff. 2009. Invasive species can also be native. Trends Ecol. Evol. 24:585, doi: https://doi.org/10.1016/j.tree. 2009.07.003

van Kleunen, M., F. Essl, J. Pergl, G. Brundu, M. Carboni, S. Dullinger, R. Early, P. Gonzalez-Moreno, Q.J. Groom, P.E. Hulme, C. Kueffler, I. Kuhn, C. Maguas, N. Maurel, A. Novoa, M. Parepa, P. Pysek, H. Seebens, R. Tanner, J. Touza, L. Verbrugge, E. Weber, W. Dawson, H. Kreft, P. Weigelt, M. Winter, G. Klonner, M. Talluto, and K. Dehnen-Schmutz. 2018. The changing role of ornamental horticulture in alien plant invasions. Biol. Rev. Camb. Philos. Soc. 93:1421-1437, doi: https:// doi.org/10.1111/brv.12402.

Vining, K.J., R.N. Contreras, M. Ranik, and S.H. Strauss. 2012. Genetic methods for mitigating invasiveness of woody ornamental plants: Research needs and opportunities. HortScience 47:1210-1216, doi: https://doi.org/10.21273/HORTSCI. 47.9.1210.

Voigt, T. 2002. Unmowed roughs save money and time. Turfgrass Trends 11:12, 14-16.

Vorderbruggen, M. 2006. Foraging Texas: Lyreleaf sage. 19 Oct. 2020. <https:// foragingtexas.com/2006/02/lyreleafsage.html $>$.

Voth, R.D. 1984. Weed control in dormant turf grass with glyphosate. 19 Aug. 2020. <https://www.cabdirect.org/cab direct/abstract/19860783148>.

Walther, G.-R., A. Roques, P.E. Hulmes, M.T. Sykes, P. Pysek, I. Kuhn, M. Zobel, S. Bacher, Z. Botta-Dukat, H. Bugmann, B. Czucz, J. Dauber, T. Hickler, V. Jarosik, M. Kenis, S. Klotz, D. Minchin, M. Moora, W. Nentwig, J. Ott, V.E. Panov, B. Reineking, C. Robiner, V. Semenchenko, W. Solarz, W. Thuiller, M. Vila, K. Vohland, and J. Settele. 2009. Alien species in a warmer world: Risks and opportunities. Trends Ecol. Evol. 24:686-693, doi: https://doi.org/10.1016/j.tree.2009. 06.008 .

Warren, C.R. 2007. Perspectives on the "alien" versus "native" species debate: A critique of concepts, language and practice. Prog. Hum. Geogr. 31:427-446, doi: https://doi. org/10.1177/0309132507079499.

Weidlich, E.W.A., F.G. Florido, T.B. Sorrini, and P.H.S. Brancalion. 2020. Controlling invasive plant species in ecological restoration: A global review. J. Appl. Ecol. 57:1806-1817, doi: https://doi.org/ 10.1111/1365-2664.13656.

Williams, N.S.G., A.K. Hahs, and P.A. Vesk. 2015. Urbanisation, plant traits and the composition of urban floras. Perspect. Plant Ecol. Evol. Syst. 17:78-86, doi: https://doi.org/10.1016/j.ppees.2014. 10.002 . 
Wilson, S.B., J. Rycnya, Z. Deng, and G. Knox. 2021. Summary of 26 heavenly bamboo selections evaluated for invasive potential in Florida. HortTechnology 31:367-381.

Wisconsin Department of Natural Resources. 2019. Invasive species best management practices: Urban forestry. 11 Mar. 2021.
$<$ https://councilonforestry.wi.gov/Pages/ InvasiveSpecies/UrbanForestry.aspx $>$.

Wood, C. 2019. Lyre-leaf sage: An assertive native. 11 Mar. 2021. <https://www.farm villeherald.com/author/cynthia-wood/>.

Woodlanders. 2021. Chasmanthium latifolium. 14 Mar. 2021. < https://wood landers.net/index.cfm $>$.
Young, K. and D. Cram. 2018. Control cholla cactus. New Mexico State Univ. Guide B-804. 12 Mar. 2021. <https:// aces.nmsu.edu/pubs/_b/8804/welcome. html>.

Zimmerman Smith, E. 2017. Environmentally responsible landscaping for bluebirds and other birds. 6 July 2020 . <https://www.sialis.org/plants.htm>. 